\title{
FROM YelLOW TO BLUE - OR NOT?
}

\author{
SVETLANA D. KLEYNER
}

\section{Introduction}

Looking for the word goluboj 'light blue' in Russian etymological dictionaries, one gets a rather confusing picture: Vasmer (1953: 432-3) links it to the word golub' 'a pigeon', then says it is probably related to Lith. gulbe 'a swan' and Russ. zheltyj 'yellow', but in the very next sentence he asserts that Old Pruss. gulbis 'a swan' is not really an option, whereas Lith. gelumbe 'blue fabric', OPruss. gelimbas 'blue fabric' might be an interesting parallel. Chernykh (1999: I.202) without reservation links the Russian word to the IE root*ghelwhich means 'yellow'. Both mention Lat. columba, but say that the initial /k//g/ correspondence is impossible. On the whole, Russian etymological dictionaries favour the 'from yellow to blue' explanation. ${ }^{1}$

This would not be a unique semantic development. The root * ghel-can be seen in Russian words for 'yellow' and 'green', in Greek $\chi \lambda \omega \rho o ́ s$, in Skt. hari-, Lat. heluus etc. The most interesting example is the semantic switch from yellow to blue seen in Celtic languages, where, along with OIr. gel 'white', we find OIr. glas, a 'greyish-blue' colour, which stems from the same IE root, *ghel-. This root's shift of meaning in Russian would therefore represent a curious semantic parallel with the Celtic languages, but would by no means be unique. C. Biggam (2012: 180) cites Pokorny as evidence for the lexemes given above (including goluboj) being derived from * ghel- to prove that, at an early stage of development, the colour concept 'grue' included blue.

However, there are certain problems with this point of view. The first problem with this etymology is the fact that, for Russian, this would mean three basic colour terms coming from the same root *ghel- (zholtyj 'yellow', zelenyj 'green' and goluboj 'light blue'). This sometimes happens with two colours (cf. English black and blue), but that three should be derived from the same root would be an extremely rare - if not unique - case. ${ }^{2}$ The second problem is the absence of satemization in both Russian and Baltic forms. The $* g$ - in the root is palatalized, as shown by zelenyj and Avest. zairi. ${ }^{3}$

\section{Latin columba}

At this point, we have to look at Lat. columba and see if this word, although it cannot be connected with goluboj phonetically, could help find some answers.

\footnotetext{
${ }^{1}$ With the exception of R. Derksen (2007: 175), who states that the suffix *-mbh is frequent in bird names (of which the only example in Russian would be jastreb 'a hawk'), but the root is unclear.

${ }^{2}$ On the status of Russian goluboj as BCT see Paramei 2005.

${ }^{3}$ The Baltic words for 'swan' are not satemised; this confirms that we are dealing with a different root.
} 
Etymological dictionaries of the Latin language offer several clues. The dictionaries of Walde-Hoffman and Ernout-Meillet both state that there is a distinct parallel between the Latin and Russian words. But then the paths diverge. In Latin, there were two words for 'pigeon': columba for the domesticated species and palumbes for the wild or feral one. The ErnoutMeillet dictionary (EM 1967: 134) states that the first element in columba

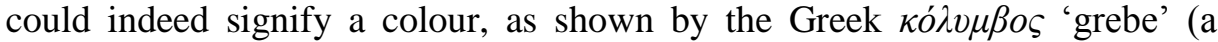
dark-coloured bird) along with $\kappa \dot{\lambda} \lambda \alpha \imath v o \varsigma$ 'dark', whereas the first element in palumbes could also signify a colour and be part of the Latin palleo group (Skt. palitah, Russ. polovyj etc., the colour being 'pale' or 'grey'). The dictionary of Walde-Hoffman, in contrast, while citing the same Greek parallels, combines the roots together and offers a common root * qel- (1938: 282 ), which explains the initial $p$ - $/ k$ - variation as a reflection of one of the major dialectal differences between the Sabellic and Latino-Faliscan branches of Italic languages. M. de Vaan (2008: 126-7) is the only one to assert a 'nonIE impression' of the word, although he places palumbes (ibid., 442) together with Greek $\pi \dot{\varepsilon} \lambda \varepsilon \imath \alpha$ 'wild pigeon' (and thus the palleo group) and states that the suffixal development was analogous to the same development in columba.

Despite these proposed explanations, it is impossible to find a single ancestor root for the Russian and Latin words. Firstly, the previously mentioned Russian $g$ - versus Latin $c$ - cannot be simply explained away. Secondly, the Latin itself is difficult to explain. If columba and palumbes come from the same root, the *qel-proposed in Walde-Hoffman leads nowhere: it does not correspond to Greek initial $k$ - in the proposed parallels (Greek has $t$ - or $p$ - in such cases, but never $k$-). Thirdly, Latin, Russian, Greek and Baltic have the -umbo formant at the end; many scholars mention this fact, but few actually try to explain it. H. Frisk, one of those who did attempt an explanation, explains this formant as *-nbho (Frisk 1960: I.905-6), but this is not supported by Greek: the words with *-nbho, like $\dot{\varepsilon} \lambda \alpha \varphi \circ \varsigma$, show no trace of * $b$. One could propose *-mbo, as was done by such early scholars as Petersson (1916: 30), but at present we are well aware of the problems presented by the virtually-absent PIE $* b$, and, given the contexts for those very few instances where it can be reconstructed (such as $* m l-* b l$ or $* \mathrm{pH}_{3}-* b$, and a couple of well-known roots), it is highly improbable that this is one of the cases where we might have $* b$.

Lockwood (1990: 261-3) claimed that Russian, Baltic and Greek words have little or nothing to do with the Latin ones, but this claim does not seem very productive because of the obviously similar end-word formant that seems to be a unique or almost unique occasion in all these languages except Greek. In contrast, R. Beekes considers $-u m b-/-u b$ - to be a pre-Greek suffix, which would indicate that the word is pre-Greek, and, therefore, not IE (2003: 2.3). 
It should be quite obvious by now that goluboj has no connection with *ghel-. In order to find out what connections it does have, we have to look at all the known words that resemble this formation.

\section{Possible parallels}

One parallel has already been proposed by Persson (1910: 33). Not knowing, probably, about Greek $\kappa o ́ \lambda v \mu \beta o \varsigma$, he makes an attempt to unite the two Latin words, columba and palumbes, each stemming, in his opinion, from the different roots I have already mentioned, with the word for 'lead', plumbum. Although the *-bho suffix he proposes is, in light of everything we have so far seen, quite improbable (as improbable as his ideas of a freely alternating first consonant in the root he reconstructs), the basis on which he drew this idea could stand some ground despite later criticism.

The origin of Lat. plumbum is obscure. A common theory associates it with Greek molubdos, which currently seems redundant to many scholars. C. Melchert supports Beekes' hypothesis of molubdos being a separate Lydian loan-word, and suggests a meaning 'dark metal' (Melchert 2008: 153-5). Indeed, plumbum was connected with Old Irish luaide by Beekes (2010: II, 964), but he does not explain how the *dho- suffix changed into -umb, and the etymology is not very good semantically, as 'lead' in this case would mean 'malleable', whereas the names for metals in IE, when they do have an internal meaning and were not borrowed from a non-IE source, tend to derive their names from

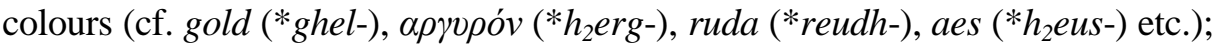
Melchert's etymology of molubdos fits this pattern (although it does not explain the variety of forms we see in Greek), ${ }^{4}$ but Beekes' etymology does not.

\section{Non-IE?}

The only way to explain the difference in the initial consonant is by the root being a loanword from a non-Indo-European language. This often happens with names of metals and birds, and we do not know many of the sources of such borrowings. For example, Greek khalkos and Russian zhelezo are also quite often thought to have originated from a single non-Indo-European source (Ivanov 1983: 101-2), and one could note some similarity between the inconsistency of the initial consonant of these words with that of golub' $\kappa o ́ \lambda v \mu \beta o \varsigma$. It is quite clear such inconsistencies do occur when the source language of the loan possessed a sound that cannot be readily identified with any that exist in the target language. ${ }^{5}$

It is also quite clear that some loaned words undergo 'folketymologisation' in the target language; thus, we have zont in Russian, because the source-word zondeck looks as if it were formed like shar-ik, 'little ball';

\footnotetext{
${ }^{4}$ See Eckerman (2005: 183-189) for the possible versions.

${ }^{5}$ See Beekes (2003: 5.6) for his pre-Greek labiovelars.
} 
Russ. gavkun (a type of seagull; the name suggest a barking sound, but the origin lies in Finnic gahka); English primrose (from primerole); It. bergamotta (the name does not come from the town of Bergamo, but from Turkish begarmudi 'prince of pears'); or, an even more complicated example, male and female in English being structured like man and woman, but having no relation to each other. It is therefore quite probable that the source of all the words which are the subject of this paper, from golub' and golimbas to palumbes,

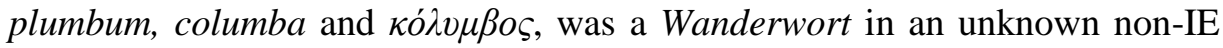
language. The languages that acquired the word may have tried to interpret the initial sound as well as they could or some sort of connection with roots already existing in these languages was formed. What remains is its meaning.

\section{Conclusion}

In Russian, we have a word for colour, and a word for a bird from the same

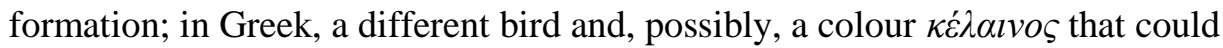
have been perceived as a related word; in Baltic, a word for yet another bird (although this bird is white), and that for a blue fabric; in Latin, we have a bird, or, perhaps, two birds (or two words for one bird) and maybe a darkcoloured metal. This looks like a narrow group of similarly-looking words of obscure origin, the meanings of which are centered on birds and colours.

Naming a colour after a bird is not common, but it happens (cf. voronoy 'black (horse)' vs. Russ. voron 'raven', and possibly Greek $\gamma \lambda \alpha v \kappa o ́ \varsigma ~ ' g r e y i s h-$ blue' vs $\gamma \lambda \alpha \tilde{u} \xi$ 'owl'). Naming a bird after a colour is more common, and we even have names like Greek $\chi \alpha \lambda \kappa i \varsigma$ 'coppery' for a bird that could be the European roller, where the metal gave rise to the word which was used to describe the colour, which was then used to signify the bird. On the other hand, it is quite difficult to imagine the need for borrowing such a complex word to simply signify a dark colour. A probable solution is that the word came along with some kind of bird, and that bird was some species of pigeon. There is no reconstructed word for 'pigeon' in IE, and rock doves, the pigeons most familiar to us now, were not that common in ancient times (Gibbs, Barnes \& Cox 2001: 177). This bird used to live in India, Asia Minor, North Africa and in the very south of Europe (e.g. Spain, Greece and Italy). Rock doves spread with domestication, carrying their name with them, and the word started to signify a colour in Slavic, as happened, for example, with Greek $\gamma \lambda \alpha v \kappa o ́ s$, and, perhaps, through the name of the colour or some kind of reinterpretation in Latin, it came to signify a dark, bluish metal.

The link between Russ. goluboj and IE*ghel-, as well as the semantic parallel with Celtic languages, can therefore be considered non-existent.

Institute for Linguistic Studies, RAS, St. Petersburg 


\section{References}

Beekes, R.S.P., 2003, Pre-Greek Loanwords in Greek, at http://iedo.brillonline.nl/dictionaries/content/greek/loanwords.html, last accessed on 25/05/2013.

Beekes, R.S.P., 2010, Etymological Dictionary of Greek, Leiden: Brill. Biggam, C.P., 2012, The Semantics of Colour: a Historical Approach, Cambridge: CUP.

Chaitraine P., 1977, Dictionnaire étymologique de la langue grecque, 2 T. Paris: C. Klincksiek.

Chernyx, P.Yа., 1999, Историко-этимологический словарь современного русского языка. [Historical and Etymological Dictionary of Modern Russian], Moscow: Russkij yazyk.

De Vaan, M., 2008, Etymological Dictionary of Latin and the Other Italic Languages, Leiden: Brill.

Derksen, R., 2007, Etymological Dictionary of the Slavic Inherited Lexicon, Leiden: Brill.

Eckerman, C., 2005, 'Tò $\beta$ ó $\lambda$ нov in the Lease Inscriptions of the Klytidai', Zeitschrift für Papyrologie und Epigraphik 154, 183-9.

Ernout, A., Meillet, A., 1967 Dictionnaire étymologique de la langue latine Histoire des mots, Paris: C. Klincksiek.

Frisk, H., 1960, Griechisches etymologisches Wörterbuch, Bd.1, Heidelberg: C. Winter.

Gibbs, D., Barnes, E. \& Cox, J., 2001, Pigeons and Doves: a Guide to Pigeons and Doves of the World, London: Pica Press.

Ivanov, V.V., 1983, История славянских и балканских названий металлов. [A History of Slavic and Balkan Names of Metals], Moscow: Nauka.

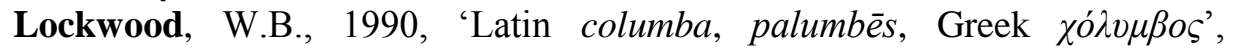
Historische Sprachforschung. Historical Linguistics, 103-2, 261-3.

Melchert, H. C., 2008, 'Greek Molybdos as a Loanword from Lydian', in: Collins, B.J., Bachvarova, M.R., Rutherford, I., eds., Anatolian Interfaces: Hittites, Greeks and their Neighbours, Oxford: Oxbow books, 153-7.

Paramei, G., 2005, 'Singing the Russian Blues', Cross-cultural research 39, 10-38.

Persson, P., 1910, Beiträge zur Indogermanischen Wortforschung, Bd. 1, Uppsala.

Petersson, H., 1916, Baltisches und Slawisches, H. Ohlsson.

Vasmer, M., 1953-1958, Russisches Etymologisches Wörterbuch Bd. 1-3, Heidelberg: C. Winter.

Walde, A., Hoffman, J.B., 1938, Lateinisches etymologisches Wörterbuch. Bd.1, Heidelberg: C. Winter. 
